\section{TUMOURS ASSOCIATED WITH A VIRUS INFECTION IN AN INSECT}

\author{
By F. T. BIRD \\ Division of Entomology, Department of Agriculture,
} Ottawa

$\mathrm{R}$ EPORTS of tumours in insects are relatively rare. Pailloty mentions proliferation in the fat cells of Euxoa slgetum Schiff., following infection by virus diseaseg (pseudo-grasseries I and II). Tumours have been described in the fruit-fly, Drosophila melanogester Meigen, by $\operatorname{Stark}^{2,3,4}$ and Russell ${ }^{5}$; in larvo of the Pygæra group of butterflies, by Federley ${ }^{6}$; and in the stick insect, Dixippus morosus Br., by Pflugfelder ${ }^{7}$. They have been found in a large Orthopteran insect, Leucophaea maderce F., by Scharrer ${ }^{8}$.

All the tumours so far discovered in insects are apparently non-malignant, although malignancy has been claimed by Stark $^{2}$ and Federley ${ }^{6}$. Russell ${ }^{5}$ found that those in Drosophila reported by Stark as malignant were similar in structure to benign tumours occurring in the same insect, and that the so-called malignant tumours could be successfully transplanted without hampering the development of the host. The tumour strains discovered by Federley apparently have been lost.

Various stimuli will provoke tumour proliferations in insects. Spontaneous tumours occur in several genetic tumour strains in the fruit-fly, but the stimulus is not known. Russell suggests that certain abnormalities which occur in the mid-gut epithelium of the lethal 7 strain may cause abnormal cell proliferations. In the stick insect, proliferation accompanies cell degeneration following the removal of the corpora allata, organs of internal secretion. In Leucophoea, Scharrer has shown that tumours are formed in the mid-gut and salivary reservoir, and to a less extent in the fore-gut and salivary glands, when the recurrent nerve, which innervates these organs, is cut at various levels.

In the course of a study of a virus polyhedral disease of the European spruce sawfly, Gilpinia hercynice (Htg.) ${ }^{9}$, tumours were observed in the midgut after infection of the epithelium by the virus. The following is a brief description of the origin and nature of the tumours, pending a more detailed account of the disease to be published elsewhere.

The mid-gut epithelium of the normal sawfly larva is made up of large columnar digestive cells, a base- ment membrane, an inner circular and an outer longitudinal muscle coat. The lattice work of muscle fibres covers but a part of the epithelial cells; in many places these are separated from the circulating blood only by the basement membrane and a delicate connective tissue sheath. Among the large digestive cells there are groups or nidi of small basal, embryonic or regenerative cells located just beneath the basement membrane. The function of the regenerative nidi is (1) to propagate cells, (2) to replace the large cells when the latter are exhausted by digestive activities, (3) to add to the number of digestive cells during the moulting periods of young larvæ, and (4) to replace the digestive epithelium at the time of the last larval moult and during pupation.

During the moulting period of a young larva, new cells are passed gradually from the regenerative nidi into the digestive epithelium. This is accomplished without any appreciable increase in the size of the nidi. At the time of the last larval moult, the digestive epithelium is completely replaced. The digestive cells disintegrate slowly and at the same time there is an increase in the number of cells of each regenerative nidus. A new mid-gut is formed when adjacent nidi converge. All the cells do not enter into the functional epithelium. A few remain at the bases of the digestive cells, where they form the regenerative nidi of the new mid-gut. Most of the materials of the old larval gut are absorbed, but an indigestible part is evacuated after ecdysis. Soon after this evacuation, the larva spins a cocoon and at this stage is termed an eonymph. The mid-gut of the eonymph is similar to that of the young larva. It is a temporary gut, however, and soon the digestive cells again disintegrate, and cells are propagated by the regenerative nidi to form the adult mid-gut.

In the diseased larva, the virus affects only the digestive cells of the mid-gut epithelium. When infection takes place and nuclear transformations occur which finally result in the formation of poly. hedral bodies, abnormal cell proliferations appear in the regions of the regenerative nidi (Fig. 1). There is no increase in the size of the nidi at this time. Apparently a few cells are released and multiply rapidly to form the proliferations. Most of these project into the body cavity, but infiltration into the cytoplasm of the digestive cells does occur. This is similar to, but more intense than, that which takes place during the moulting period of a healthy larva.

Large tumours are formed only when the larva becomes infected just prior to the last larval moult. All the materials necessary for further metamorphosis

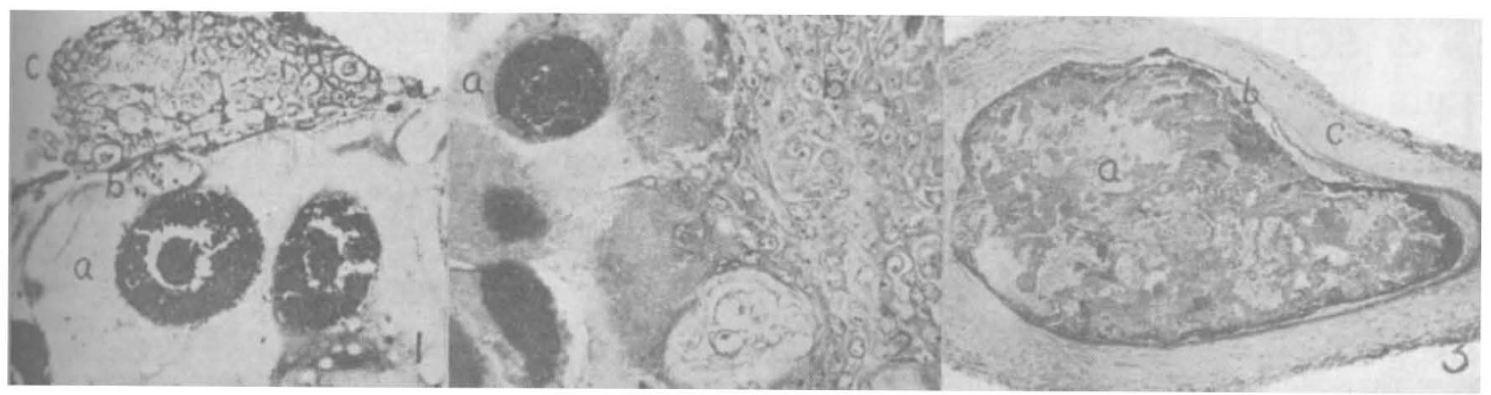

Fig. 1. Section of mid-gut epithelium of a diseased spruce sawfly larva approaching the last larval moult showing (a) characteristic granulation of nuclear material as a result of disease infection, $(b)$ regenerative nidus, and $(c)$ proliferating cells. $\times 270$

Fig. 2. Section of mid-gut epithelium of an eonymph showing (a) disease nuclei and $(b)$ proliferating cells. $\times 270$

Fig. 3. Section of a mature tumour of the spruce sawfly showing $(a)$ necrotic mass of epithelial origin, $(b)$ thin layers of tissue formed from proliferating cells, and $(c)$ a loose mass of proliferating cells. $\times 45$ 
are accumulated at this time, and normal cell proliferation and replacement takes place. When larvæ become infected at an earlier stage, death from the effect of the disease occurs before these abnormal proliferations progress very far. The infection process and abnormal cell proliferations continue in the eonymphal gut. The sizes of the tumours depend on the areas of cell infection. In the case of total infection there is a general swelling of the entire eonymphal gut. The centre of a growing tumour consists of an accumulation of dead cells. This is surrounded by greatly enlarged infected cells. The whole is surrounded by a mass of proliferating cells (Fig. 2).

The tumours rapidly mature during an early stage of pupation. Cell infection and abnormal cell proliferation cease at the time of the normal disintegration of the digestive cells of the eonymphal gut. General infection takes place after the adult gut is formed, but from the time of the breakdown of the eonymphal digestive epithelium until the adult gut is formed cell infection by the virus appears to be inhibited. If the infection process and tumour formation have not continued too far, a normal gut may be formed around the tumours and the insect survives. Many of the tumours remain within the gut during pupation. Because the mid-gut of the adult is much shorter than that of the eonymph, some of the tumours may be pushed out into the body cavity during pupation, where they remain as non-living, hard, dark-brown pellets throughout the life of the adult. Those which remain within the gut are subject to the action of digestive juices and may disappear. The mature tumour consists of a necrotic, pigmented mass of epithelial cells surrounded by thin tissue layers formed from the small proliferating cells (Fig. 3).

There is no evidence of infiltration of the tumour cells into any other organ in the spruce sawfly. All the evidence indicates that the tumours are nonmalignant.

${ }^{1}$ Paillot, A., Ann. des Epiphyties et Phytogenetique, 2, N.S., 341 (1936), 'Stark, M. B., J. Cancer Res., 3, 278 (1918).

s Stark, M. B., J. Exp. Zool., 27, 509 (1919).

- Stark, M. B., Amer. J. Cancer, 31, No. 2, 253 (1939).

'Russell, S. E., J. Exp. Zool., 84, 363 (1940).

- Federley, H., Hereditas, 22, 193 (1936).

7 Pflugfelder, O., Z. wiss. Zool., 151, 149 (1938).

${ }^{8}$ Scharrer, B., Proc. Soc. Exp. Biol. and Med., 60, 184 (1945).

- Balch, R. E., and Bird, F. T., Sei. Agric., 25, 2 (1944).

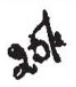

\section{SOUTH-EASTERN UNION OF SCIENTIFIC SOCIETIES}

$\mathrm{T}$ HE fifty-thrd annual congress of the SouthEastern 4 id Sof Scientific Societies was held at Canterbury D. Ang April 19-23, at the invitation of the May/r and dorporation, with the co-operation of the Dean laind Chapter.

In hits address the president, Mr. F. H. Edmunds, district geologist for south-east England in the Geological Survey, gave a broad picture of the evolution of State Geological Surveys in the various countries of the world. He indicated how their inception, in the first half of the nineteenth century, was intimately linked with the birth and growth of the science of geology, which itself is but some 150 years old. The basic principles of geological science were formulated largely as the result of the work of James Hutton in
Scotland and William Smith in England; Smith produced the first real geological map. Once these principles had been grasped, the economic importance of the geological map became immediately apparent to Governments everywhere. The Geological Survey of Great Britain was established in 1835, and it was almost immediately followed by those of Canada and India. To-day practically every civilized country in the world possesses its Geological Survey.

Mr. Edmunds said that geological research is the scientific study of the foundation of all our surround. ings, and its application touches us, either directly or indirectly, in our everyday life in many directions; one obvious way is in assisting in the discovery of economic minerals-coal, oil, minerals, etc.-and there are also numerous other less apparent ways. Geological maps of a country which give detailed accurate data of the surface layers of the land are particularly valuable in densely populated countries, in connexion with the many and widespread civil engineering works which are always in progress and which vary from foundation work for buildings to bridge-building, road-making and surface water storage, reservoir and dam.building, and from digging trenches for water, gas and sewage mains to sinking wells for water supply. Geological Surveys have also a cultural function, instanced by the identification by the Geological Survey of Great Britain of the types of rock and, in many cases, of their sources, which were used in making archæological objects, such as those revealed in bombed sites in Canterbury during the Second World War.

As social development proceeds towards planning and nationalization, as it is doing in Great Britain, the influence of the work of a Geological Survey on the implementation of policies becomes very great. Again quoting Great Britain, Mr. Edmunds said that not only was the Geological Survey the official adviser to the Coal Board, but its work also provides the basic data for decisions by central and local planning authorities relative to such matters as where and how sand, gravel, building stones, brick, cement, etc., should be quarried or manufactured ; indeed, no other basic criteria exist. The search for natural reserves of underground water has long been the function of the Geological Survey; without this previous work, regulation and conservation of underground water, now rendered necessary largely owing to great increases in daily consumption, would be impracticable.

An address on "Roman Canterbury" was delivered to the Archæological Section by its president, S. S. Frere, who also conducted a tour of the recent excavations in the City to illustrate points in his address. The keeper of manuscripts at the Cathedral Library, W. Urry, gave a paper on "The Street Plan of Mediæval Canterbury", and later demonstrated to the members on site. Excursions to Minster, Ebbs. fleet, Sandwich and Richborough were conducted by Dr. H. Raven. Dr. George Taylor became president of the Botanical Section, the subject of his address being "Remarks upon the Genus Potamogeton". Francis Rose gave a paper upon "Gaps in our Knowledge of the Flora of Kent", and conducted an excur. sion to Stodmarsh and Trenley Park Wood.

The president of the Geological Section, Arthur Wrigley, spoke on "The Thanet Sand", and conducted an excursion to Bishopstone Gap to examine the Lower Eocene rocks. A paper on "Notes on the Minerals of the Mesozoic and Later Strata of S.-E. England" was given by J. C. Taylor. A joint 